\title{
Synergy between 3D Models and Tissue Engineering to Optimize Sinus Lift, Implant Placement and Immediate Loading in Partially Edentulous Patients
}

\author{
Lanka Mahesh, Elda Restrepo, Mónica A Restrepo
}

\begin{abstract}
Tissue engineering is a clinical approach toward the development of dynamic molecular delivery that can restore and improve regeneration. The 3D models and regenerative principles applied during implant guided dental surgery open new approaches for tissue constructs favoring sinus lift and implant placement.
\end{abstract}

Purpose: The aim of the present clinical study was to determine evidence that synergy between 3D models and bone regeneration utilizing autologous fibroblast growth factor (FGF) and growth factors matrices mixed with demineralized freezedried bone allograft (DFDBA) particles optimize tissue engineering for immediate dental implant placement and loading during sinus lift procedure.

Materials and methods: Twelve endo-osseous implants were placed into residual crestal bone $(5.0 \pm 0.15 \mathrm{~mm})$. A minimal invasive osteotome Summer's technique was performed in combination with autologous FGF matrices mixed with FDBA particles. Soft tissue height and width were measured at baseline, 1, 3 and 6 months. Engineered bone surrounding implants was analyzed through 3D metric models for volume and contact interface from baseline to 6 months.

Results: Healing was uneventful. The surgical guide and the osteotome technique significantly contribute to the initial implant stability. Gingival soft tissue improves in color and contour. Soft tissue height and width both increased from baseline to 6 months. At 1 month, soft tissue height (STH) increase was $2.55 \pm 0.30 \mathrm{~mm}(\mathrm{Cl} 95 \%-p=0.001)$, and soft tissue width (STW) gain was $1.50 \pm 0.50 \mathrm{~mm}(p=0.001-\mathrm{Cl} 95 \%)$. At 3 months, STH increased to $3.12 \pm 0.50 \mathrm{~mm}$ and STW gain was $2.40 \pm 0.40 \mathrm{~mm}(p=0.001-\mathrm{Cl} 95 \%)$. At 6 months, these values remained stable. Implant sites receiving autologous FGF matrices mixed with DFDBA exhibited a BV gain of $0.47 \pm 0.10$ $\mathrm{cm}^{3}$-bone fill averaging $100 \%$ at 6 months $(p=0.001)$.

Conclusion: The osteotome Summer's technique was a predictable technique to increase bone volume. Autologous FGF matrices mixed with DFDBA favors 3D scaffold enhancing bioguided soft tissue gain and bone engineering at implant interface. Sinus membrane perforations were favorable controlled. Guided dental surgery and three-dimensional metric applications improve surgical placement, mechanical support, clinical performance and patient cost/benefit satisfaction. Further studies with a larger sample are needed to enhance the statistical significance of our clinical findings.

Keywords: Tissue engineering, Growth factors, Sinus lifting procedure, 3D models, Implant placement.

How to cite this article: Mahesh L, Restrepo E, Restrepo MA. Synergy between 3D Models and Tissue Engineering to Optimize Sinus Lift, Implant Placement and Immediate Loading in Partially Edentulous Patients. Int J Oral Implantol Clin Res 2013;4(1):36-43.

\section{Source of support: Nil}

Conflict of interest: None declared

\section{INTRODUCTION}

Dental surgeons are frequently faced with defects in bone resulting from disease or trauma. ${ }^{1-3}$ Bioguided tissue engineering is a novel concept of cell intelligence toward the development of biological, cellular and molecular deliveries that restore and improve biomimetic processes. ${ }^{4-6}$ The bioengineering of tissues and organs, sometimes called regenerative medicine, is emerging as a science, as a technology, and as an industry. ${ }^{7,8}$

Tissue engineering is a term used to describe tissue produced in culture by cells seeded grown in various porous absorbable matrices. ${ }^{9-11}$ Autologous fibrin matrices and growth factors grafts applied during guided dental surgery open new approaches for soft tissue repair and bone regeneration. ${ }^{8,12-20}$ Normal healing is controlled by growth factors made in the body. The first growth factor application were described by Rita Leevy more than 50 years ago, but only in the last 15 years have scientist been able to clone and manufacture them in quantity. Researchers theorize that applying larger doses of these potent molecular constructs should speed the whole healing process. ${ }^{21-23}$ Growth factors also play an important role in local regulation of periodontal repair and bone regeneration favoring angiogenesis, chemiotaxis and cellular proliferation and differentiation. ${ }^{24,25}$

A variety of materials and surgical techniques are available for tissue and bone engineering. ${ }^{26-34}$ Bone substitutes may replace autogenous bone for sinus lift procedures and also can be used to augment bone vertically in extremely atrophic posterior maxilla. ${ }^{35-40}$ It remains unclear whether augmentation procedures are needed at immediate single implants placed in fresh extraction sockets; however, sites treated with bone morphogenetic proteins may enhance bone formation around implants grafted, but there is not enough evidence that support the efficacy of other molecular constructs, such as growth factors grafts in conjunction with implant treatment. ${ }^{41,42}$

Sinus lift surgery has been used by the dental profession to increase bone volume in the posterior maxilla and currently, the treatment of choice for posterior dental implant anchorage. ${ }^{43-47}$ Density of host bone is crucial for implant 
placement and stability. For some patients, implant treatment would not be an option without bone augmentation. However, the amount of alveolar bone preoperatively available for implant placement in an ideal position is often inaccurate. In most cases, the surgeon cannot tell with any certainty what structural bone quality will be available before preparing the implant site. ${ }^{48,49}$ Bone cannot be fully understood unless conceived and analyzed in three dimensional (3D) terms. Commonly used referents may include soft tissue changes, bone volume, bone surface and bone width. ${ }^{50-54}$

Guided dental surgery is a concept whereby the planning and installation of an implant is controlled to achieve precise results. ${ }^{55-61} \mathrm{~A}$ number of guided surgery possibilities exist utilizing either analogue or digital technologies. ${ }^{62-65}$ These protocols offer a controlled treatment, reduce clinical time and provide greater safety with respect to damage involving adjacent anatomical structures. ${ }^{60,66-68}$ The evolution in sophisticated diagnostic imaging modalities and associated software applications began in the late 1980s. As computing power increased, the ability to move from $2 \mathrm{D}$ to $3 \mathrm{D}$ data marked the beginning of a new challenge and exciting area ${ }^{69-71}$ Cone beam computed tomography (CBCT) data display four primary views: The axial, the panoramic, the $3 \mathrm{D}$ reconstructed and the cross-sectional. The standard for digital computed tomographic images is called DICOM, digital imaging and communications in medicine. Various third-party interactive treatment planning software can also manipulate the CBCT data in an ever-expanding array of capabilities to facilitate the diagnosis, treatment planning and surgical interventions. ${ }^{68,72-77}$

From a clinical point of view, many questions are still opened: Is there sufficient soft bone tissue to achieve an optimal result during implant placement? Is reasonable the simultaneous placement of an implant with or without hard tissue grafting? Should the hard tissue grafting be done simultaneously? What will be the best option for presurgical measurement information? What about metric accuracy? Will it be cost-effective?

The applicability of metric techniques may provide a favorable conceptualization of bone volume as well as vertical dimensions of the ridge. The aim of the present clinical study was to determine evidence that synergy between 3D models and bone regeneration utilizing autologous fibroblast growth factor (FGF) and growth factors matrices mixed with demineralized freeze-dried bone allograt (DFDBA) particles optimize tissue engineering for immediate dental implant placement and loading during sinus lift procedure.

\section{MATERIALS AND METHODS}

Twelve endo-osseous implants were placed into residual crestal bone $(5.0 \pm 0.15 \mathrm{~mm})$. All patients were systemically healthy and have no contraindications for any surgical procedure (total of 6, 4 female and 2 male). Patients with periodontal disease, or that received any antibiotic therapy 6 months before surgery and pregnant women were excluded. Prior surgical procedure a written informed consent and voluntary acceptance was obtained according to the Helsinki, 1983 protocol.

In all cases initial periodontal therapy was performed, consisting in plaque control, oral hygiene motivation, scaling, root planning and coronal polishing. Elimination of decay and handling the occlusal trauma was included when necessary.

\section{Integration of Visible Image, X-rays and CBCT}

The 3D metric values were obtained from images models, periapical and panoramic X-rays to elaborate the surgical guide. 3D submilimetric measurements were also evaluated for soft tissue height (STH) and width (STW) from baseline, 1, 3 and 6 months (Figs 1A, C and G).

Engineered bone was measured to evaluate bone volume gain (mm) and fill (\%) and, to determine surrounding bone apposition by bone contact interface (BC) during healing from baseline to 6 months.

\section{Growth Factors Bioguided Molecular Process}

Autologous fibrin and growth factors matrices were obtained prior the surgical procedure using a vacuum collection system. A $20 \mathrm{ml}$ of blood drawn from the most common point, median cubital vein which is pushed by means of a double-pointed needle into a vacuum tube (Fig. 2A). After labeling, the sample became mixed and blended for 5 minutes over a blood roller mixer. A cellular sweeping of the plasma concentration was carefully manipulated to obtain selective molecular fraction preserving platelet integrity. The jellification process begins immediately after adding 5 units volume of the ionic fraction using an insulin syringe (ionic content $\mathrm{Mg}^{++}, \mathrm{Zn}^{++}, \mathrm{Na}^{+}, \mathrm{K}^{+}, \mathrm{Ca}^{++}$and $\mathrm{Cl}^{-}$). Once a consistent gel texture was obtained (appx. $30 \mathrm{~min} /$ room temperature) autologous FGF matrices were mixed with demineralized freeze dry bone allograft particles $(1,000$ microns diameter) (Fig. 2B).

\section{Guided Dental Surgery}

Twelve endo-osseous implants $(4.3 \times 13 \mathrm{~mm})$ were placed into residual crestal bone $(5.0 \pm 0.15 \mathrm{~mm})$ utilizing a custom fabricated cast-based surgical guide made of polymerized 

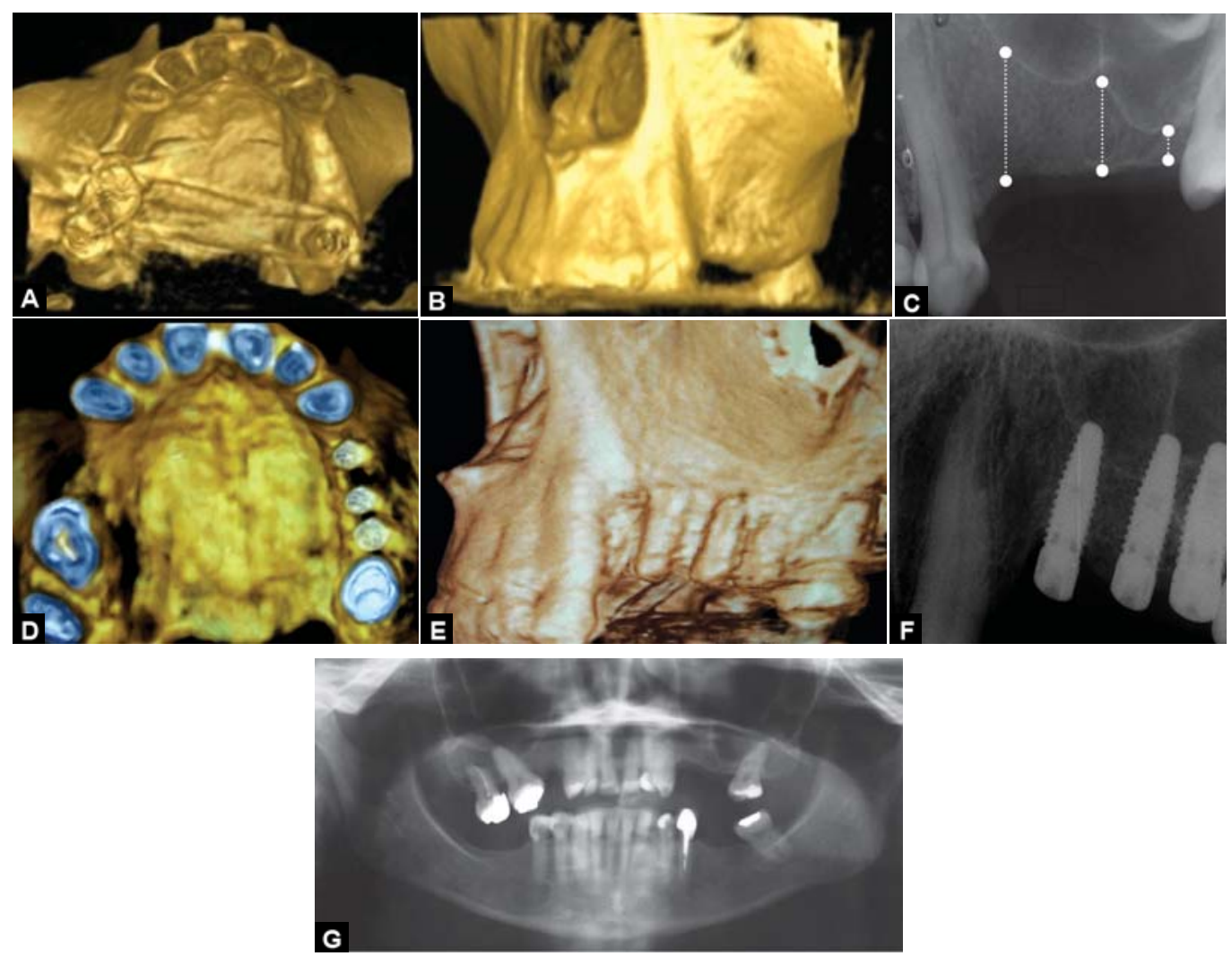

Figs 1A to G: Metric models integration and image models to evaluate bone volume gain and surrounding bone apposition during healing: (A) Baseline occlusal CBCT view, (B) baseline lateral CBCT view, (C) preoperative X-ray metric analyzes to evaluate bone and soft tissue height and width, (D) postoperative occlusal CBCT view, (E) lateral CBCT view of engineered bone surrounding endosseous implants and soft tissue at 6 months, $(F)$ postsurgical $X$-ray metric analyzes to evaluate endosseous implant placement, $(G)$ initial panoramic X-ray
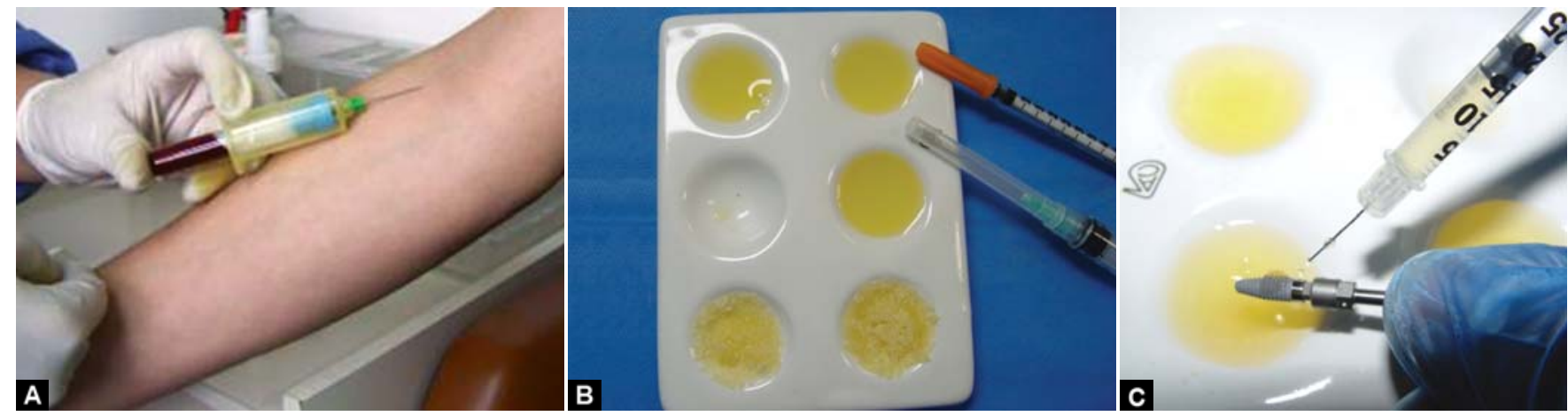

Figs 2A to C: Growth factors bioguided molecular process: (A) Autologous fibrin and growth factor matrices were obtained prior the surgical procedure using a vacuum collection system. A $20 \mathrm{ml}$ of blood drawn pushed by means of a double-pointed needle into a vacuum tube, (B) autologous FGF matrices were mixed with demineralized freeze dry bone allograft particles during jellification state (C) autologous FGF in liquid state configuration were used to irrigate implant surface before implant placement

resin. Acrylic sleeves were attached to the guides for accurate implant placement in a prosthetically driven position (Figs 3A to $\mathrm{G}$ ).

A minimal invasive osteotome Summer's technique was performed for lifting up to $5 \mathrm{~mm}$ from original floor height sinus. Once the osteotomy was accomplished autogenous FGF matrices were inserted and pushed inside utilizing a filler flat instrument to lift up the sinus membrane and to minimize damage to the Schneiderian membrane. Simultaneously, autologous FGF matrices mixed with
DFDBA particles were applied to treat inadequate ridge morphology and/or alveolar deficiencies. Immediate loading was considered at the same surgical appointment. Implants were restored with crowns or short fixed partial dentures at 6 months (Figs 4C and F).

\section{Statistical Analysis}

All analysis was made by means of the averages estimation and its respective intervals of confidence. In addition, a statistical t-test was used to identify differences between 


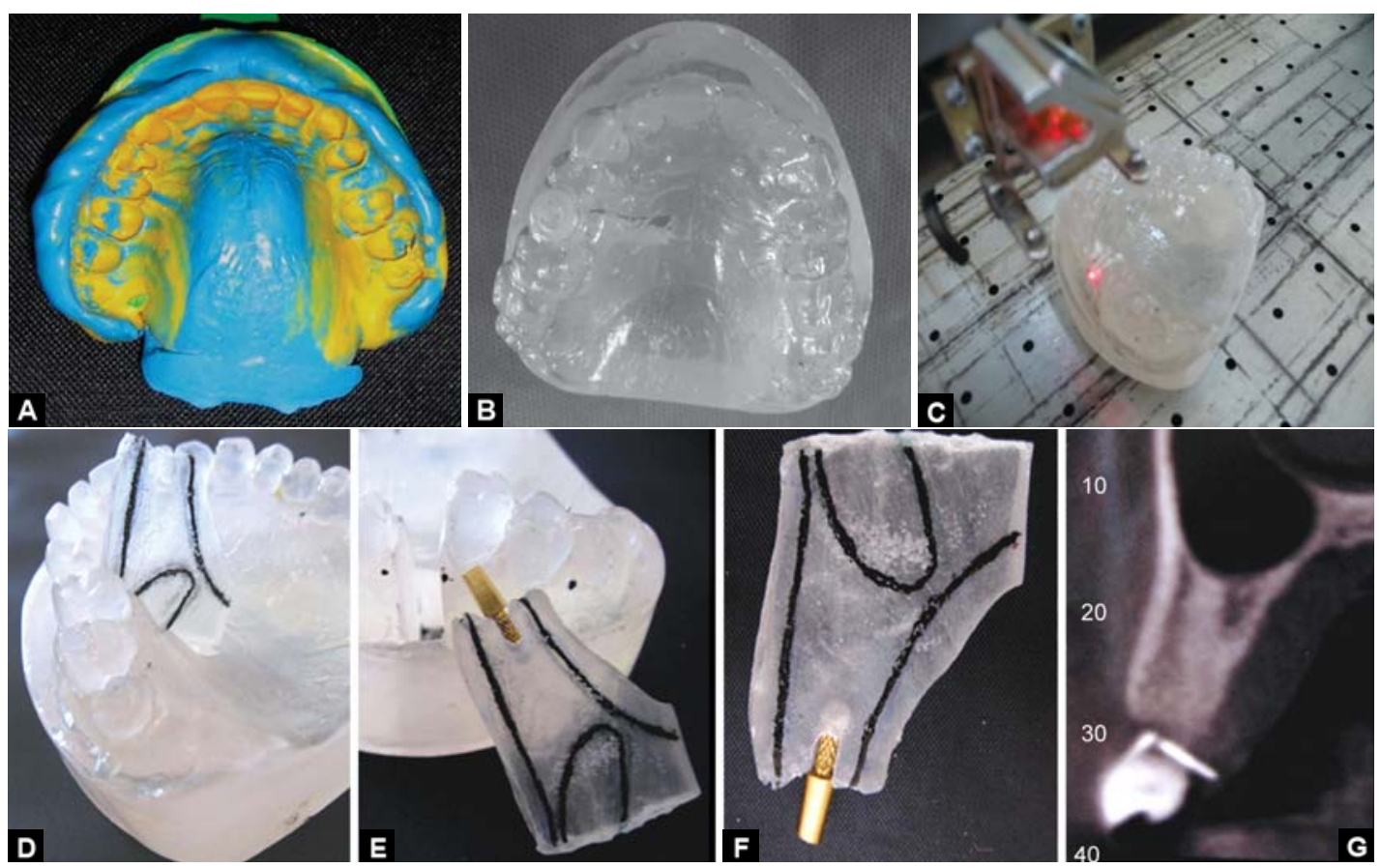

Figs 3A to G: Integration of visible image, X-rays and CBCT for custom cast-based surgical guide fabrication and accurate implant placement in a prosthetically driven position: (A) Silicone impression, (B) acrylic high melting model-design, (C) laser cutting and obtention of a manufacturing die, (D) die mapping based in 3D submillimetric osseous measurements, (E) pin indicator for implant position, (F) pin accurate position for implant placement, $(\mathrm{G})$ soft tissues submillimetric 3D measurements

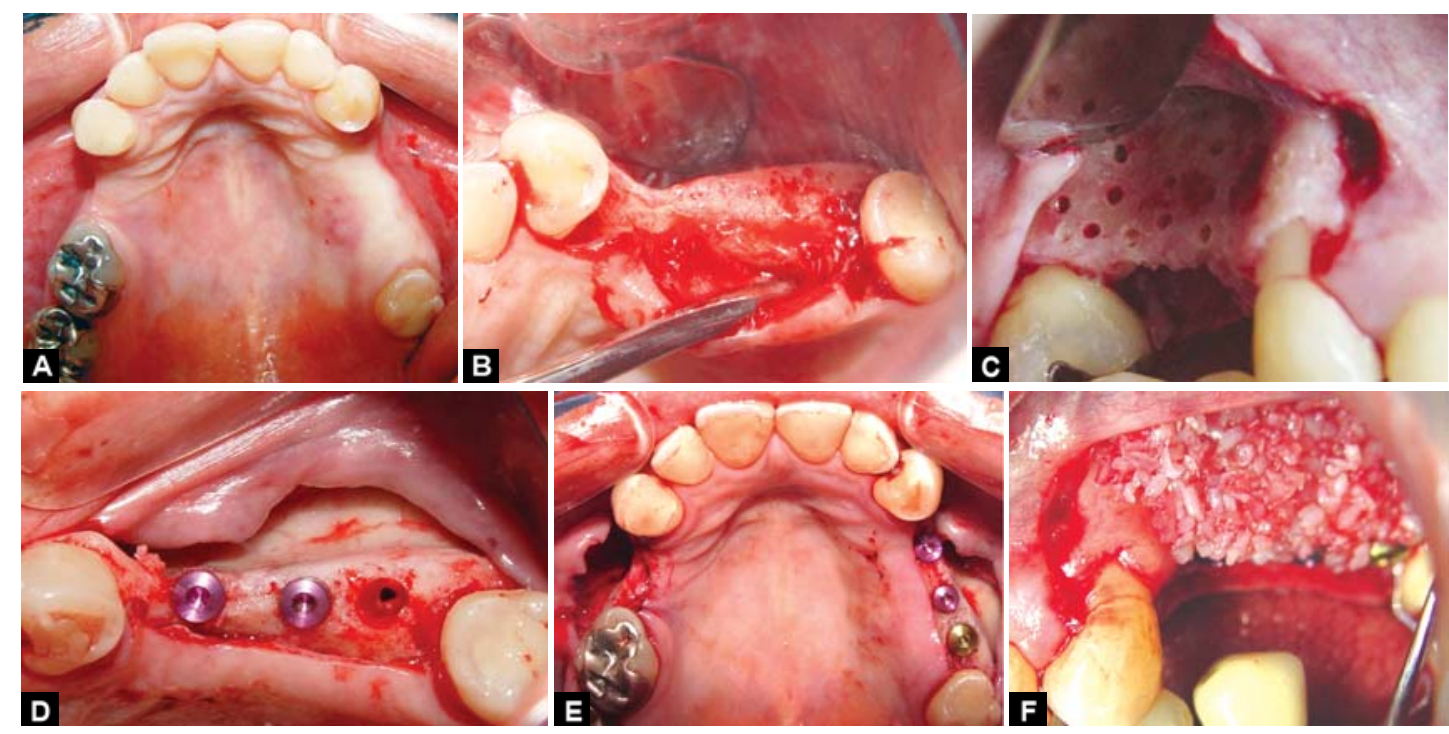

Figs 4A to F: Guided surgery for sinus lifting and implant placement: (A) Occlusal image of initial clinical overview, (B) residual bone architecture prior surgical procedure, $(C)$ bone conditioning and bleeding to improve tissue regeneration and soft tissue adaptation (D) minimally invasive osteotome Summer's technique and sinus lifting. The sinus floor is elevated and augmented with autologous growth factor and fibrin matrices following a conservative opening created on the residual bone, (E) guided surgery and implant placement, (F) guided bone plate regeneration utilizing particulated bone allograft and autogenous growth factors and fibrin

groups and differences over time within groups. The level of significance was set at $\mathrm{p}=0.001$ value.

\section{RESULTS}

Sinus lift floor was a predictable technique to increase bone volume and consequently, immediate implant placement. The 12 endo-osseous implants were successfully placed into residual crestal bone $(5.0 \pm 0.15 \mathrm{~mm})$ and the osteotome Summer's approach made a significant contribution to the initial stability of implant during placement surgery (see Fig. 4F).

Guided dental surgery remarkable offered precise clinical results for accurate implant placement in a prosthetically driven position. The use of a well-designed clinical surgical guide improved clinical mechanical support; reduce clinical time, patient cost/benefit satisfaction and safety-respect damage involving adjacent anatomical structures (Figs 4A, B and E). 
The nanostructured third-generation bioactive autologous fibrin and growth factors matrices due to is high porosity structure and plasticity properties provided suitable microenvironments for optimal recovery of bone architecture and tissue topography (Fig. 2C).

The use of autologous FGF matrices mixed with DFDBA promoted 3D scaffold enhancing bioguided soft tissue gain and bone engineering. Additionally, there were no complications related to the sinus lift surgery and sinus membrane perforations were favorable controlled (Figs 1F and 4D).

Realistic goals of submilimetric measurements highly integrate visible image models with the 3D applications and measurements. Healthy peri-implant gingival contour significantly improved esthetic results in tissue-regenerated sites. Gingival STH and STW showed a significant gain from baseline to 6 months (Figs $1 \mathrm{~A}$ to $\mathrm{D}$ and F). At 1 month, STH increased $2.55 \pm 0.30 \mathrm{~mm}(\mathrm{CI} 95 \%-\mathrm{p}=0.001)$, and STW gain was $1.50 \pm 0.50 \mathrm{~mm}$ ( $\mathrm{p}=0.001-\mathrm{CI} 95 \%)$. At 3 months, STH gain increases to $3.12 \pm 0.50 \mathrm{~mm}$ and STW gain was $2.40 \pm 0.40 \mathrm{~mm}$ ( $\mathrm{p}=0.001-\mathrm{CI} 95 \%)$. At 6 months, these values remained stable (Graph 1 ).

Engineered bone was determined by visualizing periapical, panoramic radiographs and CBCT readings (Fig. 1E). Implant sites receiving autologous FGF matrices mixed with DFDBA exhibited a bone volume gain of $0.47 \pm$ $0.10 \mathrm{~cm}^{3}$ and bone fill averaging to $100 \%$ at 6 months $(p=0.001)$ (Graph 2). Similar findings were found for increasing bone contact interface (baseline $5.0 \pm 0.10 \mathrm{~mm}-$ $30-40 \%)$ increased at 1 month to $5.45 \pm 1.55 \mathrm{~mm}(20-40 \%)$,

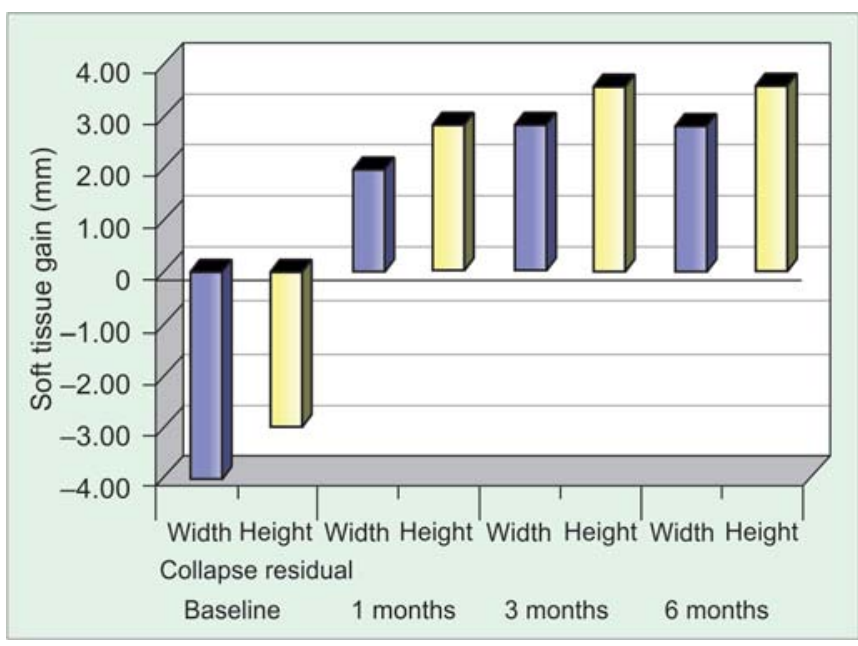

Graph 1: Soft tissue measurements: Gingival soft tissue height (STH) and width (STW) showed a significant increase from baseline to 6 months. At 1 month, soft tissue height increases to $2.55 \pm$ $0.30 \mathrm{~mm}(\mathrm{Cl} 95 \%, \mathrm{p}=0.001)$, and soft tissue width gain was $1.50 \mathrm{~mm} \pm 0.50 \mathrm{~mm}(\mathrm{p}=0.001, \mathrm{Cl} 95 \%)$. At 3 months, height increases to $3.12 \mathrm{~mm} \pm 0.50 \mathrm{~mm}$ and width gain was $2.40 \pm 0.40$ $\mathrm{mm}(\mathrm{p}=0.001, \mathrm{Cl} 95 \%)$

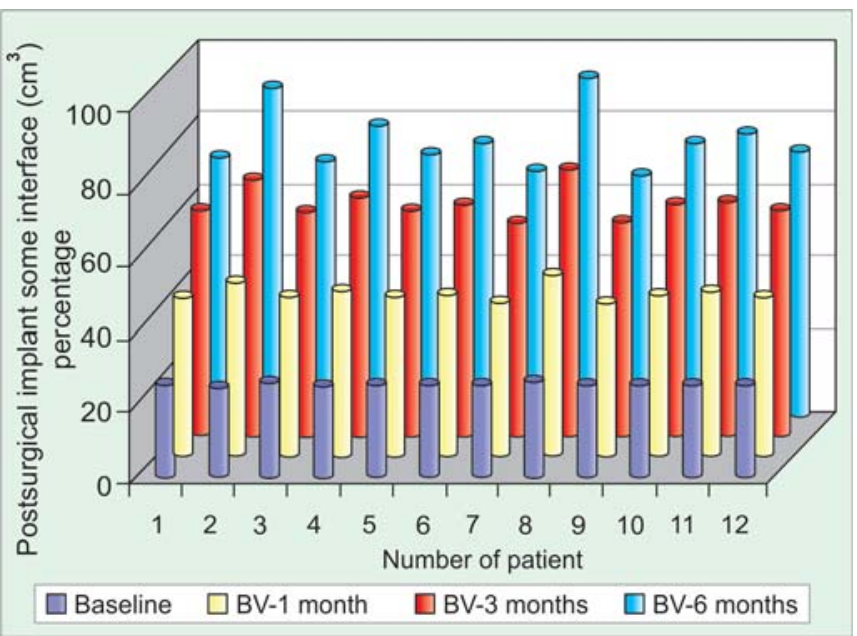

Graph 2: Bone volume: Implant sites receiving autologous FGF matrices mixed with DFDBA exhibited a BV gain of $0.47 \pm 0.10$ $\mathrm{cm}^{3}$-bone fill averaging $100 \%$ at 6 months $(p=0.001)$

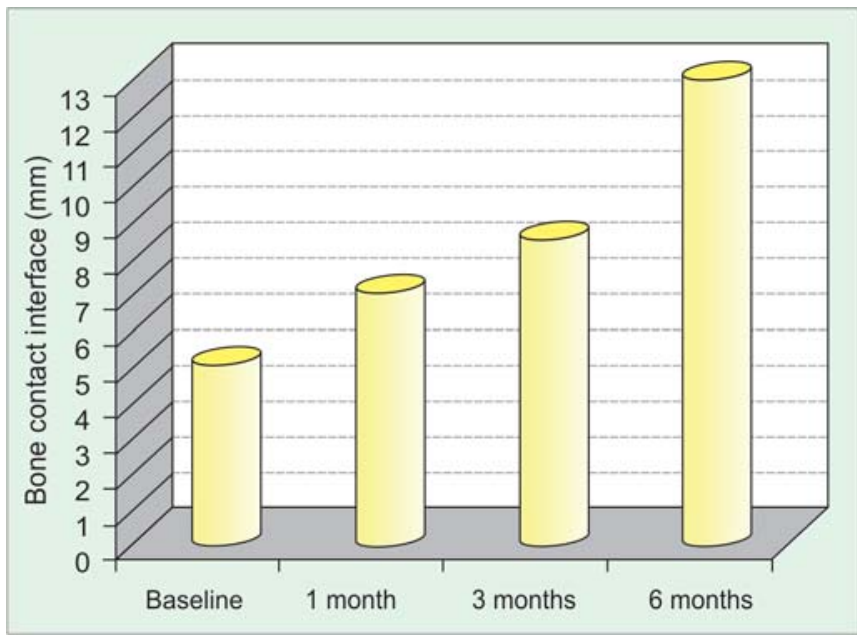

Graph 3: Bone contact interface: At baseline, BC interface surrounding implant was $5.0 \pm 0.10 \mathrm{~mm}(30-40 \%)$ engineered bone increased at 1 month to $5.45 \pm 1.55 \mathrm{~mm}(20-40 \%)$, at 3 months to $7.75 \pm 0.75 \mathrm{~mm}(40-70 \%)$ and to $10.75 \pm 2.25 \mathrm{~mm}(70-100 \%)$ at 6 months respectively

at 3 months $7.75 \pm 0.75 \mathrm{~mm}(40-70 \%)$ and $10.75 \pm 2.25 \mathrm{~mm}$ (70-100\%) at 6 months respectively (Graph 3).

\section{CONCLUSION}

The osteotome Summer's technique was a predictable technique to increase bone volume and consequently, for immediate implants placement. Autologous FGF matrices mixed with DFDBA favors 3D scaffold enhancing bioguided soft tissue gain and bone engineering at implant interface. Additionally, there were no complications related to the sinus lift surgery and sinus membrane perforations were favorably controlled. Guided surgery improves surgical placement, mechanical support, clinical performance and patient cost/benefit satisfaction. Further studies with a larger sample are needed to enhance the statistical significance of our clinical findings. 


\section{ACKNOWLEDGMENT}

We would like to thank to individuals who contributed to the research and/or the manuscript preparation.

\section{REFERENCES}

1. Johnson K. A study of the dimensional changes occurring in the maxilla following tooth extraction. Austral Dent J 1969;14:241-44.

2. Fiorellini JP, Nevis ML. Localized ridge augmentation/ preservation. A systematic review. Ann Periodontol 2003 Dec;8(1):321-27.

3. O'Brien T, James H, Erwin S. The prevention of localized deformities using regeneration. J Periodontol 1994;65:17-24.

4. Srisuwan T, Tilkorn D, Wilson J, Morrison W, Messer H, Thompson E, Abberton K. Molecular aspects of tissue engineering in the dental field: Periodontology 2000;41: 88-108.

5. Bruder SP, Cols Y. Mesenchimal stem cells in osteobiology and applied bone regeneration. Clinic Orthop 1998;Oct (355 suppl):S247-56.

6. Bartold PM, Xiao Y, Lyngstaadas SP, Paine ML, Snead ML. Principles and applications of cell delivery systems for periodontal regeneration. Periodontology 2000;41:123-35.

7. Smith DS. The government's role in advancing regenerative medicine and tissue engineering - science, safety and ethics. Periodontology 2000;41:16-29.

8. De Obarrio JJ, Arauz-Dutari JI. The use of autologous growth factors in periodontal surgical therapy: Platelet gel biotechnology: Case reports. Int J Periodontics Restorative Dent 2000;Oct 20(5):486-97.

9. Terranova V, Wikesjo UME. Extracellular matrices and polypeptide growth factors as mediators of functions of cells of the periodontium. J Periodontol 1987;58;371-80.

10. Caplan AI. Adult mesenchymal stem cells for tissue engineering versus regenerative medicine. J Cell Physiol 2007;213:341-47.

11. Caplan AI, Correa D. PDGF in bone formation and regeneration: New insights into a novel mechanism involving MSCs. J Orthop Res 2011;29:1795-803.

12. Moradian-Oldak J, Wen HB, Schneider GB, Stanford CM. Tissue engineering strategies for the future generation of dental implants. Periodontology 2000;41:157-76.

13. Matras H. Fibrin seal: The state of art. J Oral Maxillofac Surg 1985;43:605.

14. Matras $H$. The use of fibrin glue in oral and maxillofacial surgery. J Oral Maxillofac Surg 1982;40:617.

15. Anitua E. Plasma rich in growth factors: Preliminary results of use in the preparation of future sites for implants. Int J Oral Maxillofac Implants 1999 Jul-Aug;14(4):529-35.

16. Yamada Y, Ueda M, Naiki T, Nagasaka T. Tissue-engineered injectable bone regeneration for osseointegrated dental implants. Clin Oral Implants Res 2004 Oct;15:589.

17. Anitua E, Andia I, Ardanza B, Nurden P, Nurden AT. Autologous platelets as a source of proteins for healing and tissue regeneration. Thromb Haemost 2004 Jan;91(1):4-15.

18. Marx R, Carlson ER, Eichstaedt DMD, Schimmele RM, Strauss JE, Georgeff KR. Platelet-rich plasma. Growth factor enhancement for bone grafts. Oral Surg Oral Med Oral Path 1998;85:638-46.
19. Ghanaati S, Unger RE, Webber MJ, Barbeck M, Orth C, Kirkpatrick JA, et al. Scaffold vascularization in vivo driven by primary human osteoblasts in concert with host inflammatory cells. Biomaterials 2011 Nov; 32(32):8150-60.

20. Whitman DH. Platelet Gel: An autologous alternative to fibrin glue whit applications in oral maxillofacial surgery. J Oral Y Maxillofac Surg 1997;55:294-376.

21. Goldman H. Healing of periodontal wound, periodontal therapy: Chapter 23. New England Journal of Medicine 1980; Press 1988:676.

22. Anitua E, Andia I, Sanchez M, Azofra J, del Mar Zalduendo M, de la Fuente M, et al. Autologous preparations rich in growth factors promote proliferation and induce VEGF and HGF production by human tendon cells in culture. J Orthop Res 2005 Mar;23(2):281-86.

23. Hughes FJ, Turner W, Belibasakis G, Martuscelli G. Effects of growth factors and cytokines on osteoblast differentiation. Periodontology 2000;41:2006,48-72.

24. Elcin YM, Dixit V, Gitnick G. Extensive in vivo angiogenesis following controlled release of human vascular endothelial cell growth factor: Implications for tissue engineering and wound healing: Artif Organs 2001Jul;25(7):558-65.

25. Khan SN, Bostrom MP. Bone growth factors. Orthop North Am 2000 Jul;31(3):365-88.

26. Artzi Z, Tal H, Dayan D. Porous bovine bone mineral in healing of human extraction sockets. Part 1: Histomorphometric evaluations at 9 months. J Periodontol 2000;71:1015-23.

27. Garg AK, Lynch SE, Genco RJ, Marx RE. Grafting materials in repair and restoration. In: Tissue engineering-Applications in maxillofacial surgery and periodontics. Chicago: Quintessence Publishing Co 1999; Inc; 83-99.

28. Simion M, Rochietta I, Kim D, Nevins M, Fiorelli J. Vertical ridge augmentation by means of deproteinized bovine bone block and recombinant human platelet-derived growth factor-BB: A histologic study in a dog model. Int J Periodontics Restorative Dent 20060ct;26(5):415-23.

29. Ripamonti U, Renton L. Bone morphogenetic proteins and the induction of periodontal tissue regeneration. Periodontology 2000;41:2006,73-87.

30. Rabie AB, Wong RW. Bone induction using autogenous bone mixed with demineralized bone matrices. Aust Orthod J 1999 Nov;15(5):269-75.

31. Simion M, Trisi P, Piattelli A. Vertical ridge augmentation using membrane technique associated with osseointegrated implants. Int J Periodontics Restorative Dent 1994;14:496-511.

32. Froum S, Cho SC, Rosenberg E, Rohrer M, Tarnow D. Histological comparison of healing extraction sockets implanted with bioactive glass or demineralized freeze-dried bone allograft: A pilot study. J Periodontol 2002 Jan;73(1):94-102.

33. Nevins M, Mellonig JT. Enhancement of the damaged edentulous ridge to receive dental implants: A combination of allograft and the Gore-Tex membrane. Int J Periodontics Restorative Dent 1992;12:97-111.

34. Yukna R, Castellon C, Saenz-Nasr A, Owens W, Simmons J, Thunthy K, Mayer E. Evaluation of hard tissue replacement composite graft material as a ridge preservation/augmentation material in conjunction with immediate hydroxyapatite-coated dental implants. J Periodontol 2003;74:679-86.

35. Becker W, Urist M, Becker BE, Jackson W, Parry DA, Bartold $\mathrm{M}$, et al. Clinical and histologic observations of sites implanted 
with intraoral autologous bone grafts or allografts. 15 human case reports. J Periodontol 1996 Oct;67(10):1025-33.

36. Wallace $S$, Froum J. Effect of maxillary sinus augmentation on the survival of endosseous dental implants. A systematic review. Ann Periodontol 2003;8:328-43.

37. Boeck-Neto RJ. Real Gabriellio MF. Histomorphometrical analysis of bone formed alter maxillary sinus floor augmentation by grafting with a combination of autogenous bone and demineralized free-dried bone allograft or hidroxyapatite. J Periodontol 2002;73:266-70.

38. Froum S, Cho SC, Rosenberg E, Rohrer M, Tarnow D. Histological comparison of healing extraction sockets implanted with bioactive glass or demineralized freeze-dried bone allograft: A pilot study. J Periodontol 2002 Jan;73(1):94-102.

39. Simion M, Jovanovic SA, Trisi P, Scarano A, Piattelli A. Vertical ridge augmentation around dental implants using a membrane technique and autogenous bone or allografts in humans. Int $\mathrm{J}$ Periodontics Restorative Dent 1998 Feb;18(1):8-23.

40. Iasella JM, Greenwell H, Miller RL, Hill M, Drisko C, Bohra AA, et al. Ridge preservation with freeze-dried bone allograft and a collagen membrane compared to extraction alone for implant site development: A clinical and histologic study in humans. J Periodontol 2003 Jul;74(7):990-99.

41. American Academy of Periodontology. The potential role of growth and differentiation factors in periodontal regeneration (position paper). J Periodontol 2005;76:1601-22.

42. Esposito M, Grusovin MG, Coulthard P, Worthington HV. The efficacy of various bone augmentation procedures for dental implants: A Cochrane systematic review of randomized controlled clinical trials. Int J Oral Maxillofac Implants 2006 Sep-Oct;21(5):696-710.

43. Wallace SS. Maxillary sinus augmentation: Evidence-based decision making with a biological surgical approach. Compend Contin Educ Dent 2006 Dec;27(12):662-69.

44. Schleier P, Bierfreund G, Schultze-Mosgau S, Moldenhauer F, Küpper H, Freilich M. Simultaneous dental implant placement and endoscope-guided internal sinus floor elevation: Two years post-loading outcomes. Clin Oral Implants Res 2008 Nov;19(11):1163-70.

45. Urban IA, Lozada JL. A prospective study of implants placed in augmented sinuses with minimal and moderate residual crestal bone: Results after 1 to 5 years. Int J Oral Maxillofac Implants 2010 Nov-Dec;25(6):1203-12.

46. Boyne PJ, James RA. Grafting of the maxillary sinus floor with autogenous marrow and bone. J Oarl Surg 1980;38:6.

47. Sethi A, Kaus T. Maxillary ridge expansion with simultaneous implant placement: Five years results of an ongoing clínical study. Int J Oral Maxillofac Implants 2000;15:491-99.

48. Sisti A, Canullo L, Mottola MP, Iannello G. Crestal minimallyinvasive sinus lift on severely resorbed maxillary crest: Prospective study. Biomed Tech (Berl) 2012 Jan 9;57(1): 45-51.

49. Riben C, Thor A. The maxillary sinus membrane elevation procedure: Augmentation of bone around dental implants without grafts: A review of a surgical technique. Int J Dent 2012.

50. Trisi P, Rao W. Bone classification: Clinical-histomorphometric comparison. Clin Oral Implants Res 1999;10:1-7.

51. Fornell J, Johansson LÅ, Bolin A, Isaksson S, Sennerby L. Flapless, CBCT-guided osteotome sinus floor elevation with simultaneous implant installation. I: Radiographic examination and surgical technique. A prospective 1-year follow-up. Clin Oral Implants Res 2012 Jan; 23(1):28-34.

52. Zubillaga G, Von Hagen S, Simon B, Deasy M. Changes in alveolar bone height and width following post-extraction ridge augmentation using a fixed bioabsorbable membrane and demineralized freeze-dried bone osteoinductive graft. J Periodontol 2003;74:965-75.

53. Simon B, Von Hagen S, Deasy M, Faldu M, Resnansky D. Changes in alveolar bone height and width following ridge augmentation using bone graft and membranes. J Periodontol 2000;71:1774-91.

54. Moghadam HG, Cols Y, Histomorphometric evaluation of bone regeneration using allogenic and alloplastic bone substitutes. J Oral Maxillofac Surg 2004 Feb;62(2):202-13.

55. Revie Leziy SS, Miller BA. Guided implant surgery and the use of osteotomes for rehabilitation of the maxilla. Pract Proced Aesthet Dent 2006 Jun;18(5):293-95.

56. Pereira CC, Gealh WC, Nogueira LM, Garcia IR JR, Okamoto R. Piezosurgey applied to implant dentistry: Clinical and biological aspects. J Oral Implantol 2012 Jan 4[Epub ahead of print].

57. Viña-Almunia J, Maestre-Ferrín L, Alegre-Domingo T, Peñarrocha-Diago MA. Survival of implants placed with the osteotome technique: An update. Med Oral Patol Oral Cir Bucal 2012;17(5):e765-68.

58. Piano S. A simple way to plan implant positioning: the 'Stechnique’. Eur J Esthet Dent Autumn; 2011;6(3):328-41.

59. Kfir E, Goldestein M, Abramovitz I, Mazor Z, Kfir V, Kaluski E. The effects of sinus membrane pathology on bone augmentation and procedural outcome using minimal invasive antral membrane balloon elevation. J Oral Implantol 2012 Mar 5. [Epub ahead of print].

60. Kaneko T, Masuda I, Horie N, Shimoyama T. New bone formation in nongrafted sinus lifting with space-maintaining management: A novel technique using a titanium bone fixation device. J Oral Maxillofac Surg 2012Mar;70(3):e217-24.

61. Crespi R, Capparè P, Gherlone E. Osteotome sinus floor elevation and simultaneous implant placement in grafted biomaterial sockets: 3 years of follow-up. J Periodontol 2010 Mar;81(3):344-49.

62. Brägger U, Gerber C, Joss A, Haenni S, Meier A, Hashorva E, Lang NP. Patterns of tissue remodeling after placement of ITI dental implants using an osteotome technique: A longitudinal radiographic case cohort study. Clin Oral Implants Res 2004 Apr;15(2):158-66.

63. Lindgren C, Mordenfeld A, Hallman M. A prospective 1-year clinical and radiographic study of implants placed after maxillary sinus floor augmentation with synthetic biphasic calcium phosphate or deproteinized bovine bone. Clin Implant Dent Relat Res 2012 Mar;14(1):41-50.

64. Guyot M, Dubuc O, Richard NP, Dutour O. Comparison between direct clinical and digital photogrammetric measurements in patients with 22q11 microdeletion. Int J Oral Maxillofac Surg 2003 June;32(3):246-52.

65. Jemt LT. Photogrammetric measurements of implant positions. Description of a technique to determine the fit between implants and superstructures. Clin Oral Implants Res 2003;5(1):30-36.

66. Summers RB. The osteotome technique: Part 3. Less invasive methods of elevating the sinus floor. Compendium 1994;15: 702-04. 
67. Taschieri S, Corbella S, Saita M, Tsesis I, Del Fabbro M. Osteotome-mediated sinus lift without grafting material: A review of literature and a technique proposal. Hindawi Publishing Corporation. Int J Dent 2012, Article ID 849093, 9 pages.

68. Taschieri S, Corbella S, Del Fabbro M. Use of plasma rich in growth factor for Schneiderian membrane management during maxillary sinus augmentation procedure. J Oral Implantol 2012;38(5):621-27.

69. Mol A, Van de Stel APF. Application of digital image analysis in dental radiography for the description of periapical bone lesions: A preliminary study. (Special tissue in dentistry) Trans Biomed Eng 1991;38:357-59.

70. Palioto DB. Sato S. Computer assisted image analysis methods for evaluation of periodontal wound healing. Braz Dent $\mathrm{J}$ 2001;12(3):167-72.

71. Ganz SD. Cone beam computed tomography-assisted treatment planning concepts. Dent Clin North Am 2011 Jul;55(3):515-36.

72. Peck JN, Conte GJ. Radiologic techniques using CBCT and 3-D treatment planning for implant placement. J Calif Dent Assoc 2008 Apr;36(4):287-90.

73. Fienitz T, Schwarz F, Ritter L, Dreiseidler T, Becker J, Rothamel D. Accuracy of cone beam computed tomography in assessing peri-implant bone defect regeneration: A histologically controlled study in dogs. Clin Oral Implants Res 2012Jul;23(7):882-87.

74. Leziy SS, Miller BA. Guided implant surgery and the use of osteotomes for rehabilitation of the maxilla. Pract Proced Aesthet Dent 2006 Jun;18(5):293-95.
75. Beretta M, Cicciù M, Bramanti E, Maiorana C. Schneider membrane elevation in presence of sinus septa: Anatomic features and surgical management. Hindawi Publishing Corporation. Int J Dent 2012;Article ID 261905, 6 pages.

76. Ganz SD. Computer-aided design/computer-aided manufacturing applications using CT and cone beam CT scanning technology. Dent Clin North Am 2008 Oct;52(4):777-808.

77. Chung S, McCullagh A, Irinakis T. Immediate loading in the maxillary arch: Evidence-based guidelines to improve success rates: A review. J Oral Implantol 2011 Oct; 37(5):610-17.

\section{ABOUT THE AUTHORS \\ Lanka Mahesh (Corresponding Author)}

Private Practice, The Dental Centre, S-382, Panshila Park New Delhi-17, India, e-mail: drlanka.mahesh@gmail.com

\section{Elda Restrepo}

Biological and Biomedical Science, Bacteriology. Andes University Bogota, Colombia, Scientific Director at Tisular Regenerative Institute IRT, Bogota, Colombia

\section{Mónica A Restrepo}

Periodontist and Master in Oral Biology, Boston University, Goldman School of Dental Medicine, Boston, Founder and Adjunct Assistant Professor, Department of Periodontology, Colegio Odontologico Colombiano, Private Practice Limited to Bone Regeneration and Periodontal Plastic Surgery, Bogota, Colombia 